\title{
Observation of Teacher Activity in Teaching Science in Elementary School
}

\author{
Zaiyasni $^{1}$, Y Helsa $^{2}$ \\ \{zaiyasni@fip.unp.ac.id\} \\ ${ }^{1,2}$ Universitas Negeri Padang. Jln Prof. Hamka, Air Tawar, Padang, Indonesia
}

\begin{abstract}
The research was motivated by the results of the National Final Exam School Year 2016/2017 at Pauh Elementary School. It turns out that the average value of natural science is lower than in other subjects. The purpose of this study was to look at the activities of teachers in teaching science in elementary schools in Pauh sub-district. This type of research is descriptive research to see, review and describe the conditions that exist in the field regarding the activities carried out by elementary school teachers. The chosen place is a public elementary school in the Pauh sub-district area of Padang, specifically the fifth grade. Results of the research show that teacher skills in conducting activities that involve students actively, arouse students' motivation, learn demonstration activities are still in an insufficient category. It is concluded that some teachers in Public Elementary School in Pauh sub-district have conducted activities in science learning. The implication of this research is as a foundation for the development of science learning in the future.
\end{abstract}

Keyword : Teacher, Elementary.

\section{Introduction}

Based on the results of the National Final Exam school year 2016/2017 at Pauh Elementary School, it turns out that the average value of natural science is below the average of other fields. This is because teachers tend to pursue curriculum targets that have been outlined. To complete all materials on time, the teacher takes the method of transferring everything in the textbooks to the students. Evaluation is given solely to obtain and collect the value of students' knowledge without thinking to explore the causes of the achievement of student learning values. The results of subsequent observations and interviews with classroom teachers show that all teachers must teach all fields of study, except religion and sports, as a result, science lessons tend to be less optimally implemented, also the teaching tools are less utilized as it should.

Science learning in elementary school is an interaction between students and their surroundings, this causes science learning to prioritize the role of students in teaching and learning activities. Thus the learning becomes student-centered earning while teachers work as facilitators. Learning in skills can be interpreted to understand a concept, teacher gives students the opportunity to acquire and discover concept through student experience by developing basic skill such as making conclusions, thus to conduct simple research the development stages include: (1) observation, (2) classification, (3) interpretation, (4) 
prediction, (5) hypothesis, (6) controlling variables, (7) planning and carrying out research, ( 8) inference, (9) application, and (10) communication [1].

To apply activities above, teachers are required to manage learning that can provide stimulation to students in learning. It means that teachers must carry out these activities optimally to bring efficacy to students, especially in teaching science to elementary school students. From the description above, it can be concluded that some of the activities carried out by the teacher determine the success of student learning in taking science lessons given by the teacher, especially in elementary schools. The better activities are undertaken by the teacher, the better the learning outcomes obtained by students.

Based on the facts stated above, the skills process will make students more creative in learning science, hence the learning objectives of science will be optimal. Therefore, researchers only want to see the activities of elementary school teachers in the learning process. The activity is the teacher's effort to make students active in the science learning process. This makes researchers interested in researching an observation of teachers activities in teaching science in elementary schools. The purpose of this study, in general, is to get a picture of the teacher's activities in teaching science to fifth-grade elementary school students, namely (1) Involving students actively in teaching science in elementary schools. (2) Generating student motivation in participating in the science learning process in elementary schools. (3) using teaching aids/media in teaching science in elementary school.

\section{Method}

This is descriptive research. Descriptive research is research intended to investigate the circumstances, conditions, or other things mentioned, presented in the form of research reports[2]. According to the explanation above, this research aims to see, review and describe the conditions in the field regarding the activities carried out by elementary school teachers. The time used for conducting this research is to process data from July to December 2016 (6 months). The population in this study are elementary school teachers teaching science in the fifth grade of Pauh Elementary School, Padang, West Sumatra. The researcher examined the teacher while teaching science in the fifth grade of elementary school. While the number of teachers as respondents is 6 out of 6 public elementary schools in Pauh Districtt.

\section{Result and discussion}

From the research that has been done regarding the activities of elementary school teachers in learning science in the District of Pauh. The data obtained are as follows

\subsection{Involve students actively}

The observation results show that teacher's activity in involving students in the Pauh Elementary School is less than sufficient $(45.4 \%)$, it is still not as expected. Based on the results of the questionnaire distributed to the teacher, it appears that the teacher uses a lot of lecture methods in teaching science. Besides, teachers rarely use learning media during the learning process. This is also supported by the results of researchers' documentation of natural science learning tools in elementary schools. The researcher's documentation focuses on 
learning tools such as lesson plans and learning media. The science lesson plans used by teachers are still using the explanation method. The lesson plan does not seem to vary. In addition to the lesson plans, the instructional media used by teachers do not vary. It is seen in the learning device that no teacher is using learning media in science. Based on this it can be concluded that the teacher in science learning does not actively involve students.

Science learning is learning that requires active students [3] [4] [5]. Science learning is learning related to natural phenomena that involve reasoning in the analysis of natural phenomena [6] [7]. Therefore the process of learning science to elementary school students must directly involve students. This is due to knowledge of science can be found with activities in the surrounding environment.

Science learning requires an investigation of nature [8] [9] [10]. Therefore, science contains values, attitudes, and processes. These three domains are related to demand for the activeness of students to achieve them. Science learning must be able to require students to actively ask questions, express ideas, question ideas obtained, be active in writing, design, summarize, make find something.

\subsection{Generating student motivation}

Based on observations showing that the activities of teachers in arousing student motivation in learning science in Elementary School District of Pauh are almost enough (70.8\%). This is also supported by a questionnaire distributed to elementary school teachers in the science learning process. The results of the questionnaire can be concluded that teachers often provide verbal and nonverbal motivation. Verbal motivation is carried out by the teacher by giving compliment such as congratulations, good and great when students do something right while non-verbal motivation by giving a thumbs up, clapping and rubbing the head. Besides, from the documentation, the researchers also found that in the lesson plan the teacher gives rewards to students in the form of "achievement stars" if students can carry out their tasks well. From this, it can be concluded that the teacher can motivate students in the learning process. Although the motivation provided is not optimal.

Learning motivation is one of the keys to learning success [11] [12] [13] [14]. Learning motivation is an encouragement that encourages students to learn [15] [16] [17]. Learning motivation can originate from within and from outside [18]. The inner factor comes from the individual's self impulse to move to do something. External factors are all things that come from outside. One that can cause motivation is the teacher [19] [20]. The teacher must be able to motivate students sustainably. This is due to the motivation given by the teacher to improve the quality of learning [21] [22] [23]. This is because the teacher may provide positive encouragement thus students can be active in learning.

\subsection{Demonstration in learning}

From observations about the demonstration in learning, the data obtained are almost enough $(70.6 \%)$, this means that there are still teachers giving abstract science material. This is supported by a questionnaire given to teachers who concluded that teachers still use conventional methods in the learning process. This is also reinforced from the lesson plan made by the teacher.

The demonstration is a way the teacher conveys information to students. The teacher's demonstration in learning will determine the quality of the teacher's learning process. Therefore an effective learning planning is needed. Effective teacher demonstration is a demonstration that can foster and facilitate the learning process [24] [25] [26]. Demonstration 
of effective learning is a teacher can use the time in the learning process to the fullest [27]. Also, teachers must use learning resources that are appropriate and suitable for the characteristics of elementary school students [28]. Elementary school students are students in the concrete operational period [29]. Therefore we need teachers who can provide learning resources following students' excellence. Demonstration of effective learning is also learning that designs learning opportunities for students to apply their learning experiences and be willing to repeat if necessary [30].

Based on research, in general, the activities undertaken by teachers in learning science in the Pauh Elementary School have not reached a good level yet and only a part of the teachers who carry out appropriate science learning activities.

\section{Conclusions}

Based on the research data above, in general it can be said that: (1) Most of the teachers in Elementary Schools in Pauh District are still less active in involving students actively, (2) Most of the teachers in Elementary Schools in Pauh District have enough activities to arouse student motivation, (3) Most of the teachers in Elementary Schools in Pauh District have had sufficient activities in using the demonstration in learning.

Based on the conclusions listed above, the researchers suggest the following matters: (1) The results of this study may be used as material for consideration to provide guidance to elementary school teachers in the Pauh District, especially in increasing teacher activity in actively involving students, arousing motivation students and the use of visual aids in learning. (2) Given the lack of teacher activity in involving students, teachers must get practice training in developing active learning patterned process skills, besides elementary school teachers need to increase their knowledge and skills in learning science. (3) This research only reveals the activities of Elementary School teachers in Pauh district in learning science in general, thus further researchers must disclose more specifically to improve science learning in elementary schools. (4) In learning science, more process skills are required, students should be learning to do various activities such as observing, classifying, applying, and so on.

\section{Acknowledgment}

Thank you to Universitas Negeri Padang for permitting this research.

\section{References}

[1] S Sulistyorini 2007 Pembelajaran IPA Sekolah Dasar (Semarang: Tiara Wacana)

[2] A Suharsimi 2010 Penelitian Tindakan Untuk Guru, Kepala Sekolah, dan Pengawas (Yogyakarta : Aditya Media)

[3] Tandogan R O and Orhan A 2007 Online Submission 371

[4] Freeman S et al 2014 Proceedings of the National Academy of Sciences 1118410

[5] Yoder J D and Hochevar C M 2005 Teaching of psychology 3291

[6] Hermansyah D and Witarsa R 2017 PrimaryEdu-Journal of Primary Education 137

[7] Kanu M A 2015 IOSR Journal Of Humanities And Social Science 2077

[8] Moeed A 2013 International Journal of Environmental and Science Education 8537

[9] Khusniati M and Pamelasari S D 2014 Jurnal Pendidikan IPA Indonesia 3169

[10] Shapiro B L 1996 Science Education 80535 
[11] Benware C A and Deci E L 1984 American Educational Research Journal 21755

[12] Zimmerman B J 1989 Journal of educational psychology 81329.

[13] Pintrich P R 1999 International journal of educational research 31459

[14] Benware C A and Deci E L 1984 American Educational Research Journal 21755

[15] Rugutt J and Chemosit C C 2009 Educational Research Quarterly 3216

[16] Turner J C and Patrick H 2004 Teachers College Record 1061759

[17] Williams K C and Williams C C 2011 Research in Higher Education Journal 121

[18] Jeppesen L B and Molin M J 2003 Technology Analysis \& Strategic Management 15363

[19] Ames C 1990 Teachers college record 91409

[20] Ingersoll R M and Smith T M 2003 Educational leadership 6030

[21] Benware C A and Deci E L 1984 American Educational Research Journal 21755

[22] Sulisworo D and Suryani F 2014 International Journal of Learning \& Development 458

[23] Figueira A I and Duarte A M 2011 Procedia-Social and Behavioral Sciences 291373

[24] Hofstein A and Lunetta V N 1982 Review of educational research 52201

[25] Ango M L 2002 Online Submission 1611

[26] Paris S G and Winograd P 1990 Dimensions of thinking and cognitive instruction 115

[27] Kirschner P A, Sweller J and Clark R E 2006 Educational psychologist 4175

[28] Laurillard D 2013 Rethinking university teaching: A conversational framework for the effective use of learning technologies ( London:Routledge)

[29] Kiswanto A 2017 9th International Conference for Science Educators and Teachers (ICSET 2017) vol 118 (Semarang/Atlantis Press)

[30] Whisler B L M J S 1997 The Learner-Centered Classroom And School (San Francisco: Jossey Bass Publishers) 